ORIGINAL ARTICLE

\title{
BURN CASE PREVALENCE IN DR KARIADI GENERAL HOSPITAL SEMARANG FROM 2012 TO 2014
}

\author{
Lucretya Yeniwati Tanuwijaya ${ }^{1}$, Yohanes Dona Christi Utama ${ }^{1}$, Najatullah2 \\ \& Muhamad Rizky Setyarto 2
}

1. General practitioner of St. Elisabeth Hospital, Semarang, Central Java, Indonesia; Intern participant in Plastic Reconstructive and Aesthetic Department, Prof. Dr. Margono Soekardjo Hospital, Purwokerto, Central Java, Indonesia

2. Consultant of Plastic Reconstructive and Aesthetic Department of Surgery Departement, Faculty of medicine, Universitas Diponegoro, Semarang, Central Java, Indonesia

\begin{abstract}
Background: Burns is a type of trauma that requires treatment and rehabilitation, which is still difficult and requires perseverance, a high amount of costs, and trained and skilled personnel. Morbidity and mortality of burns are relatively high, especially in developing countries where burn prevention and treatment systems are inadequate. The prevalence of burns is expected to be an advantage for the development of science in further research and could help clinicians prevent and curative burn care efforts.

Method: The study subjects were burned patients examined and hospitalized at Dr. Kariadi General Hospital, Semarang. Data from each sample's clinical examination results were then collected to be described based on gender, age, burns degree criteria, and etiology of burns.

Results: The total sample obtained was 72 samples, including 61 patients $(85.53 \%)$ with new burns and 11 nonemergency patients $(14.47 \%)$. From a total of 61 new burn patients, eight female patients $(13.11 \%)$ and 53 male patients $(86.89 \%)$ were obtained; 10 patients $(16.40 \%)$ were children (0-18 years), $50(81.96 \%)$ were adults $(18-65)$, and one patient $(1.64 \%)$ belonged to geriatric (> 65 years) ); based on the degree of the burns, seven patients $(11.48 \%)$ had a moderate degree and 54 patients $(88.52 \%)$ had a severe degree; there were 28 patients $(45.90 \%)$ who suffered burns caused by fire, 20 patients (32.79\%) due to electricity, six patients $(9.84 \%)$ caused by scald, and seven patients $(11.47 \%)$ with an unknown cause. Of the 61 new burn patients, there were five patients $(8.20 \%)$ who died.

Conclusion: Burn prevalence in Dr. Kariadi General Hospital, Semarang in 2012-2014 are mostly experienced by men, adults, with severe burn criteria, with the most common etiology is fire.
\end{abstract}

Keywords: Burns, prevalence, Dr. Kariadi General Hospital, Semarang.

Latar Belakang: Luka bakar merupakan jenis trauma yang membutuhkan perawatan dan rehabilitasi yang masih sukar dan memerlukan ketekunan, biaya yang tidak sedikit, dan tenaga yang terlatih serta terampil. Morbiditas dan mortalitas luka bakar cukup tinggi, terutama di negara-negara berkembang dimana sistem pencegahan dan pengobatan luka bakar belum memadai. Prevalensi luka bakar ini diharapkan dapat bermanfaat bagi pengembangan ilmu dalam penelitian selanjutnya dan juga dapat membantu klinisi dalam upaya preventif dan kuratif perawatan luka bakar.

Metodologi: Subyek penelitian adalah pasien luka bakar yang diperiksa dan dirawat inap di RSUP Dr. Kariadi Semarang. Data hasil pemeriksaan klinis dari setiap sampel kemudian dikumpulkan untuk dideskripsikan berdasarkan jenis kelamin, usia, kriteria berat ringan, dan etiologi luka bakar.

Hasil: Total sampel yang didapatkan adalah 72 sampel dengan rincian 61 pasien $(85,53 \%)$ luka bakar baru dan 11 pasien non-kegawatdaruratan (14,47\%). Dari total 61 pasien luka bakar baru, didapatkan 8 pasien perempuan $(13,11 \%)$ dan 53 pasien laki-laki $(86,89 \%)$; Usia anak-anak (0-18 th) sebanyak 10 pasien $(16,40 \%)$, dewasa (18-65) sebanyak $50(81,96 \%)$, dan 1 pasien $(1,64 \%)$ usia lanjut (>65 th); berdasarkan berat ringan didapatkan 7 pasien $(11,48 \%)$ luka bakar derajat sedang dan 54 pasien $(88,52 \%)$ dengan luka bakar derajat berat; didapatkan 28 pasien $(45,90 \%)$ mengalami luka bakar yang diakibatkan oleh api, 20 pasien $(32,79 \%)$ diakibatkan karena listrik, 6 pasien $(9,84 \%)$ diakibatkan karena terkena air panas, dan 7 pasien $(11,47 \%)$ tidak diketahui penyebabnya. Dari 61 pasien luka bakar baru, jumlah pasien yang hidup sebanyak 56 pasien $(91,80 \%)$ dan terdapat 5 pasien $(8,20 \%)$ yang meninggal.

Kesimpulan: Prevalensi luka bakar di RSUP Dr. Kariadi Semarang tahun 2012-2014 paling banyak dialami oleh laki-laki, usia dewasa, dengan kriteria luka bakar berat, dengan etiologi sumber panas terbanyak dari api.

Kata Kunci: luka bakar, prevalensi, RSUP Dr.Kariadi, Semarang.

Conflicts of Interest Statement:

The author(s) listed in this manuscript declare the absence of any conflict of interest on the subject matter or materials discussed.

Received: 15-03-2020, Revised: 20-07-2020, Accepted: 29-09-2020

Copyright by Tanuwijaya, et al, 2020. | P-ISSN 2089-6492; E-ISSN 2089-9734 | DOI: 10.14228/jprjournal.v7i2.286

Published by Lingkar Studi Bedah Plastik Foundation. This is an open-access article distributed under the terms of the Creative Commons Attribution-Non Commercial-No Derivatives License 4.0 (CCBY-NC-ND), where it is permissible to download and share the work provided it is properly cited. The work cannot be changed in any way or used commercially without permission from the journal. This article can be viewed at www.jprjournal.com 


\section{INTRODUCTION}

Burns is a form of tissue damage or loss caused by contact or transfer of energy from a heat source such as fire, hot water, chemicals, electricity, and radiation to the body. Burns is a type of trauma that requires maintenance and rehabilitation that is still difficult and requires perseverance, high costs, trained and skilled personnel. ${ }^{1}$

Burns cause symptoms of pain, swelling, and blister formation. ${ }^{2}$ All burns (except minor or grade I burns) can cause complications in the form of shock, dehydration, electrolyte imbalance, secondary infection, and many more. ${ }^{3}$

Burns is a public health problem. Morbidity and mortality of burns are relatively high, especially in developing countries where burn prevention and treatment systems are inadequate. Globally, 300,000 people die from burns from 11 million people with burn injuries who seek medical care every year. Many burn sufferers experience disability (morbidity), which often leads to community stigma and rejection, which will ultimately reduce the patients' quality of life.

In 2014, the World Health Organization (WHO) estimated that 265,000 deaths were occurring annually worldwide due to burns. In India, more than one million people suffer moderate-to-severe burns per year. In Bangladesh, Columbia, Egypt, and Pakistan, 17\% of children with burns suffer a temporary disability, and $18 \%$ suffer permanent disability. Whereas in Nepal, the burn was the secondhighest cause of disability. ${ }^{5}$

According to data from the American Burn Association (2015), there are 486,000 cases of burns that receive medical treatment; 40,000 of them must be hospitalized. Besides, a total of 3,240 deaths occur annually due to burns. The most common causes of burns are fire accidents, inhalation of smoke, contact with electricity, chemicals, and hot objects.

In Indonesia, the prevalence of burns in 2013 was $0.7 \%$ and has decreased by $1.5 \%$ compared to $2008(2.2 \%)$. The provinces with the highest prevalence were Papua $(2.0 \%)$ and Bangka Belitung (1.4\%) (Basic Health Research in the Indonesian Ministry of Health). The prevalence of burns is expected to be an advantage for the development of science in further research and could help clinicians prevent and curative burn care efforts.
However, there was still limited data about burn incidence, especially in Dr. Kariadi General Hospital as a referral hospital of Central Java. Therefore, the rise of burn case prevalence in Dr. Kariadi General Hospital was intended to discuss.

\section{METHODS}

The study was a cross-sectional study using secondary data obtained from medical records in Dr. Kariadi General Hospital, Semarang, between January 2012-December 2014. The Authors searched for all Medical Record data of patients who suffered burns from 2012-2014 and were treated by plastic surgeons, who met the inclusion and exclusion criteria. The inclusion criteria in this study were all patients with burns examined and hospitalized. The exclusion criteria in this study were medical records with unclear and incomplete data.

The severity of burn degree refers to the American Burn Association, which defines a moderate degree as $15-25 \%$ of $2^{\text {nd }}$ degree of a burn-in adult, $10-20 \%$ of $2^{\text {nd }}$ degree of burn-in children, or less than $10 \%$ of $3^{\text {rd }}$ degree of burn. The severe degree was defined as $25 \%$ or more of second burn degree in adult, or $20 \%$ or more of second burn degree in children, or $10 \%$ or more of third burn degree, or burn associated hand, face, ear, eye, foot, genital or perineum, or burn associated inhalation trauma, electrical injury, another trauma.

\section{RESULTS}

There were 76 burn patients with 72 patients fulfilling the inclusion and exclusion criteria based on data collection. Of these, 61 patients $(85.53 \%)$ with new or emergency burns and 11 patients $(14.47 \%)$ with non-emergency burns.

In 2012, the number of burn patients with emergency cases was 11 cases $(91.67 \%)$, and 1 case $(8.33 \%)$ of non-emergency burn injury in the form of granulation ulcers. In 2013, the number of burn patients with emergency cases was 29 cases $(90.62 \%)$, and 3 cases $(9.38 \%)$ with nonemergency burn injuries in the form of granulation ulcers, exposed bone, and dermatogen contractures. In 2014, the number of burn patients with emergency cases was 21 cases $(75 \%)$, and 7 cases $(25 \%)$ of the outpatient unit 


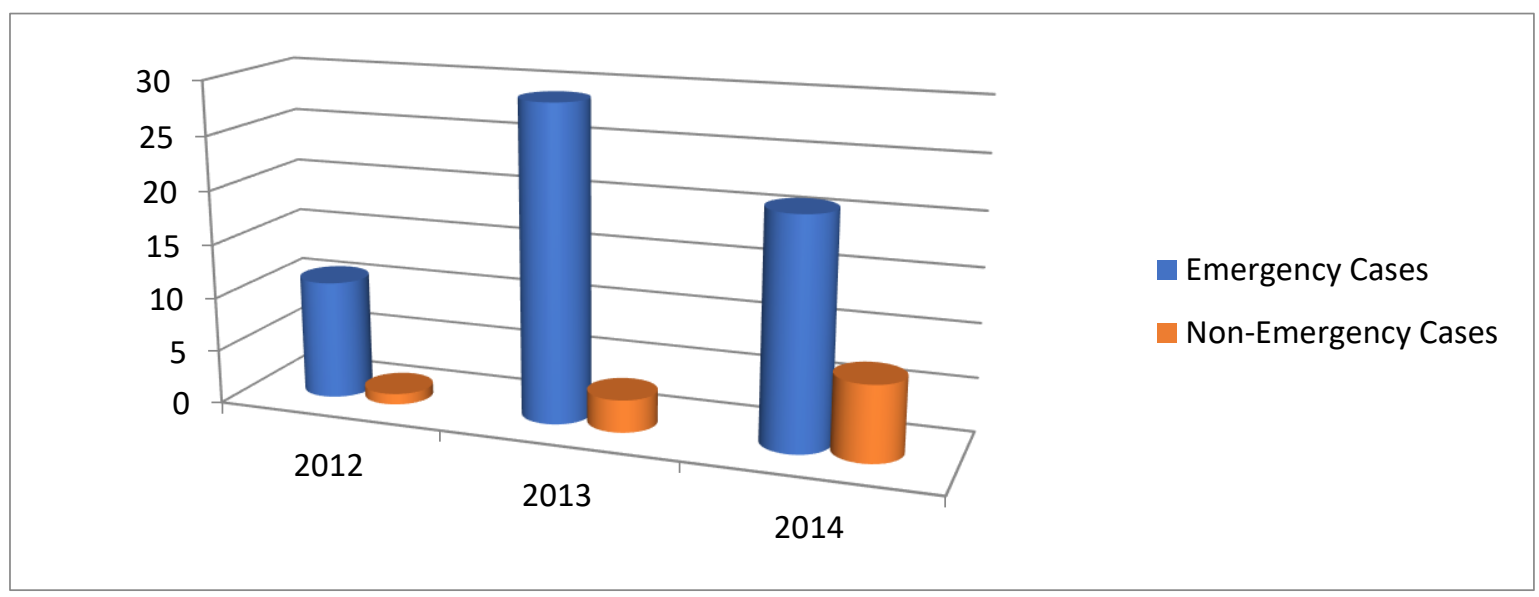

Figure 1. Yearly admission divided by emergency and non-emergency group

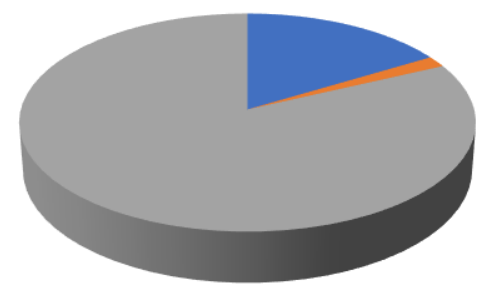

- children $=10$ $(16.40 \%)$

geriatric $=1$

$(81.96 \%)$

adult $=50$

$(1.64 \%)$

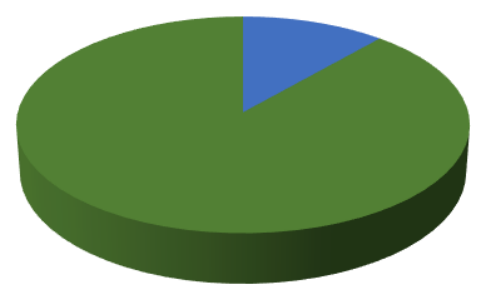

Moderate degree

- Severe degree

Figure 3. Patient admission by the degree of the hot water, 1 case due to electricity, 1 case with an unclear cause. From a total of 61 new case burn patients, the number of patients alive was 56 $(91.80 \%)$, the number of patients who died was five patients $(8.20 \%)$, in which there was one patient in 2012, 1 patient in 2013, and 3 patients in 2014.

\section{DISCUSSION}

There were 72 patients from 2012-2014 at Dr.Kariadi General Hospital. Those numbers are not as many as in other centers, such as Cipto Mangunkusumo Hospital in Jakarta and Dr. Soetomo Surabaya. ${ }^{11,12}$ This can be due to our research center's nature and demographic distribution, compared to the center data collection nature of a multi-center study. Because there is no burn unit yet in Dr.Kariadi Hospital, many burn cases are already handled by other smaller local hospitals according to each hospital's capability. 


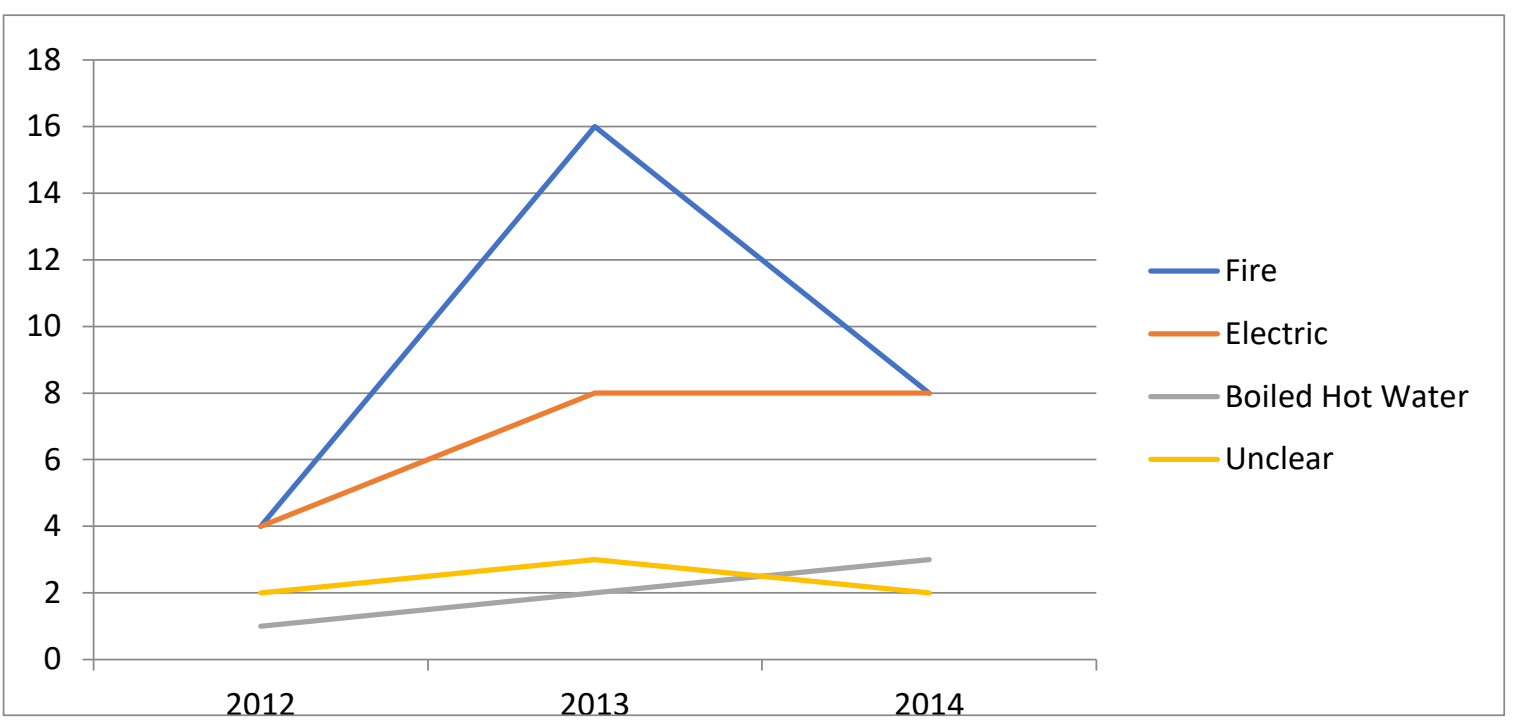

Figure 4. Yearly admission divided by etiology

Of the total 72 burn patients treated in the hospital, there were 61 (85.53\%) emergency burns cases, and 11 (14.47\%) non-emergency burn cases. The classification of those cases has not been done at other centers in Indonesia, including in Asia. ${ }^{11-}$ ${ }^{24}$ However, data recording that was carried out by Cipto Mangunkusumo Hospital in Jakarta and Dr. Soetomo Hospital, Surabaya could provide more benefits and can be used as a standard in the presentation of data on the prevalence of burn cases such as the origin of referral burn patients, the number of patients who are forced to go home of their own volition or without advice from the doctors who are on duty of the treatment, patients who have experienced inhalation trauma, type of antibiotic used. ${ }^{11,12}$

Based on gender classification, eight female patients $(13.11 \%)$ and 53 male patients $(86.89 \%)$ suffered burn injuries. These results are comparable to the high number of male patients who suffer burns at other centers in Indonesia, Singapore, India, and China. ${ }^{11,12,13,17,18}$ This can be caused by most men in the area having higher activities than women. ${ }^{25}$ However, based on the WHO reports, it shows that women are at higher risk of getting burns than men, which can be caused by high cooking activity using unsafe fires. ${ }^{5}$

Based on the age classification of emergency or new cases of burn patients in 20122014 , there were ten pediatric patients $(16.40 \%)$, 50 adult patients $(81.96 \%)$, one geriatric patient $(1.64 \%)$. These results are in line with data obtained at Dr. Soetomo Surabaya and India that burn cases were most experienced in adult patients. $12,17,20$

Based on the American Burn Association criteria of the degree of the burn, seven patients $(11.48 \%)$ had a moderate degree, 54 patients $(88.52 \%)$ had a severe degree of burns. The classification of patients with burns was not done at Dr. Soetomo Hospital in Surabaya, but rather it explained the etiology of burns compared to the patient's age. ${ }^{12}$ When compared to research at Cipto Mangunkusumo Hospital in Jakarta, they presented the data of each extent and depth of burn analyzed separately. ${ }^{11}$

Based on the etiology classification of burns in emergency cases, the first most common cause was a fire $(n=28 ; 45.90 \%)$, and the second most common cause was electrical trauma $(\mathrm{n}=$ 20; 32.79\%). These are in line with Hidayat and colleagues' research at Dr. Soetomo Hospital Surabaya, with the first highest etiology is fire, followed by electrical trauma and hot water. ${ }^{12}$ At other centers in Cipto Mangunkusumo Hospital, Jakarta, it showed a result that is quite similar for the most common etiologies, in which the first is fire, continued sequentially by hot water and electrical trauma. ${ }^{11}$

It is necessary to add data on the origin of the referral and job characteristics for each patient, as well as data collection on the number of fluids provided in the treatment of burns, the existence of comorbid such diabetes, hypertension, and concomitant as other trauma that accompanies, classification of household or work accident in 
order to obtain more holistic characteristics of burn cases to be analyzed in Dr.Kariadi Hospital.

\section{CONCLUSION}

It could be concluded that burns are mostly experienced by men, adults with severe burn criteria, and the most common etiology is fire. It is necessary to complete data to analyze, which helps medical staff, especially reconstructive and aesthetic plastic surgeons, general surgeons, and general practitioners, provide more precise and accurate treatment for promoting, preventive, curative, and rehabilitative in burn patients.

Correspondence regarding this article should be addressed to:

Lucretya Yeniwati Tanuwijaya. ; Intern participant in Plastic Reconstructive and Aesthetic Department, Prof. Dr. Margono Soekardjo Hospital, Purwokerto, Central Java, 50164, Indonesia.

E-Mail: lucretya.tan@gmail.com

\section{ACKNOWLEDGEMENT}

The principal author would like to express deep gratitude to the supervisor, Muhamad Rizky Setyarto, as a plastic reconstructive and aesthetic consultant for the guidance, enthusiastic encouragement, and useful critiques of this research work. The primary author would also like to thank Najatullah for his permission to burn data collection in Kariadi General Hospital and his professional advice. The main author also appreciates Yohanes Dona Christi Utama for his assistance and support in keeping this work's progress on schedule.

\section{REFERENCES}

1. Noer MS, Saputro ID, Perdanakusuma DS. Penanganan Luka Bakar: Airlangga University Press; 2006.

2. Grace, Pierce A, Borley NR. At a Glance Ilmu Bedah : Third edition: Erlangga; 2006.

3. Rismana E, Rosidah I, Prasetyawan, Olivia B; Erna. Efektivitas Khasiat Pengobatan Luka Bakar Sediaan Gel Mengandung Fraksi Ekstrak Pegagan Berdasarkan Analisis Hidroksiprolin dan Histopatologi Pada Kulit Kelinci. Buletin Penelitian Kesehatan, 2013; 41(1): 45 - 60.
4. Stokes MAR, Johnson WD. Burns in The Third World: An Unmet Need. Switzerland: Annals of Burns and Fire Disasters, 2017;30(4):243-6.

5. WHO Media Center Fact Sheets: Burns. 2014. Available from: http://www.who.int/mediacentre/factsh eet/fs365/en/.

6. Young AW, Graves C, Kowalske KJ, Perry DA, Ryan CM, Sheridan RL, Valenta A, Conlon KM, Jeng JC, Palmieri T. Giudeline for Burn Care Under Austere Conditions: Special Care Topics. Journal of Burn Care and Research, 2017;38(2):497-509.

7. Badan Penelitian dan Pengembangan Kesehatan Kemenkes RI. Riset Kesehatan Dasar, 2013.

8. American College Of Surgeons Commitee On Trauma. Advanced trauma life support (ATLS) student course manual 9th edition. American College of Surgeon, 2012.

9. Thorne $\mathrm{CH}$. Grabb and Smith's Plastic Surgery: 7th Edition: Lippincott Williams \& Willkins; 2014.

10. Hukmas. Profil Kami. 2019. Available at: https://www.rskariadi.co.id/page/162/ Profil-Kami/Profil

11. Wardhana A, Basuki A, Prameswara ADH, Rizkita DN, Andarie AA, Canintika AF. The epidemiology of burns in Indonesia's national referral burn center from 2013 to 2015. Burns Open, 2017; 1(2): 67-73.

12. Hidayat T, Noer MS, Saputro ID. Five years retrospective study of burns in DR Soetomo General Hospital Surabaya. Folia Medica Indones, 2014; 50: 123-130.

13. Hwee J, Song C, Tan KC, Tan BK, Chong $\mathrm{SJ}$. The trends of burns epidemiology in a tropical regional burns centre. Burns, 2016; 42(3): 682-686.

14. Sharma NP, Duke JM, Lama BB, Thapa B, Dahal P, Bariya ND, Marston W, Wallace HJ. Descriptive Epidemiology of Unintentional Burn Injuries Admitted to a Tertiary-Level Government Hospital in Nepal. Asia Pacific Journal of Public Health, 2015; 27(5): 551-560.

15. Ahuja RB, Bhattacharya S. An analysis of 11,196 burn admissions and evaluation of conservative management techniques. Burns, 2002 ; 28(6):555-61. 
16. Shanmugakrishnan RR, Narayanan V, Thirumalaikolundusubramanian P. Epidemiology of burns in a teaching hospital in South India. Indian J Plast Surg, 2008; 41(1):34-7.

17. Golshan A, Patel C, Hyder AA. A systematic review of the epidemiology of unintentional burn injuries in South Asia. Journal of Public Health, 2013; 35(3):384 96.

18. Li H, Yao Z, Tan J, Zhou J, Li Y, Wu J, Luo G. Epidemiology and outcome analysis of 6325 burn patients: a five-year retrospective study in a major burn center in Southwest China. Scientific Reports, 2017; 7(1).

19. Tripathee S, Basnet SJ. Epidemiology of burn injuries in Nepal: a systemic review. Burns Trauma. 2017; 5:(1).

20. Vahdati SS, Karzar BH, Momen N. Independent predictive factors of hospitalization in a North-West Burn Center of Iran; an Epidemiologic Study. Emerg (Tehran, Iran), 2015; 3:40-44.
21. Song C, Chua A. Epidemiology of burn injuries in Singapore from 1997 to 2003. Burns, 2005;31:18-26.

22. Al-Ibram E, Rao MH, Ali SA, Saleem A. Epidemiologic profile and outcome of hospitalized burn patients: 5 years experience at burn center, civil hospital, Karachi. J Dow Univ Heal Sci Karachi, 2012;6:29-31.

23. Chien WC, Pai L, Lin CC, Chen HC. Epidemiology of hospitalized burns patients in Taiwan. Burns, 2003;29:582-8.

24. Li, H., Yao, Z., Tan, J., Zhou, J., Li, Y., Wu, J., \& Luo, G. Epidemiology and outcome analysis of 6325 burn patients: a five-year retrospective study in a major burn center in Southwest China. Scientific Reports, 2017: 7(1).

25. Lawrence JC. Burn and Scald: Aetiology and Prevention. In Settle John A. D. Principles and Practice of Burns Management. $1^{\text {st }}$ ed. Leeds, 1996: 3-25. 